\title{
Identification of Fusarium oxysporum f. sp. lactucae race 1 as the causal agent of lettuce wilt in Brazil
}

\author{
Cléia S. Cabral ${ }^{1}$, Kátia R. Brunelli² ${ }^{2}$ Hélcio Costa ${ }^{3}$, Maria Esther de N. Fonseca ${ }^{4}$, Leonardo S. Boiteux ${ }^{4}$ \\ \& Ailton Reis ${ }^{4}$
}

${ }^{1}$ Departamento de Agronomia, Universidade Federal Rural de Pernambuco, 52171-900, Recife, PE, Brazil; ${ }^{2}$ Sakata Seed Sudamerica Ltda., Bragança Paulista, 12902-001, SP, Brazil; ${ }^{3}$ Incaper, Venda Nova do Imigrante, 29375-000, ES, Brazil; ${ }^{4}$ Embrapa Hortaliças, 70351-970, Brasília, DF, Brazil

Author for correspondence: Ailton Reis, e-mail: ailton.reis@embrapa.br

\begin{abstract}
The objective of this work was to assess the virulence to lettuce cultivars and host specificity and to identify races of Fusarium oxysporum f. sp. lactucae (FOLac) isolates associated with lettuce wilt in Brazil. Thirty-one isolates identified based on morphology were inoculated in a set of lettuce cultivars for race determination. Plantlets of 'Elisa', 'Vera', and 'Red Salad Bowl' cultivars were inoculated with all isolates using a root-dipping method. Isolates were also inoculated in species of Asteraceae and other botanical families. 'Elisa' and 'Vera' were susceptible to 27 isolates while 'Red Salad Bowl' was resistant to all isolates. Plants other than lettuce were not infected by any of the isolates, suggesting their specificity to lettuce. All pathogenic isolates were assigned to race 1 and used to evaluate a PCR protocol with primers targeting race 1. Only amplicons associated with race 1 pattern were observed for all pathogenic isolates but not for one non-pathogenic isolate, thus leading us to conclude that FOLac race 1 is so far the sole causal agent of lettuce wilt in Brazil.
\end{abstract}

Key words: Lactuca sativa, Fusarium wilt, virulence, pathotypes.

\section{INTRODUCTION}

Fusarium wilt caused by Fusarium oxysporum Schlechtend.: Fr. f. sp. lactucae Matuo \& Motohashi is one of the most economically important diseases of lettuce (Lactuca sativa L. - Asteraceae) around the world. Yield losses may vary from 20 to $70 \%$ depending on the cultivar, management practices and environmental conditions (Pasquali et al., 2005; 2007). First symptoms of the disease are a poor development and an overall chlorosis. As the disease progresses, older leaves may collapse leading to plant death. An intense brownish color can be seen in the vascular vessels of diseased plants after transversal stem sectioning as a result of the host reaction to the colonization and toxin production by F. oxysporum f. sp. lactucae (FOLac) (Fujinaga et al., 2001; Garibaldi et al., 2004b; Scott et al., 2010).

Fusarium wilt of lettuce has a wide geographic distribution being reported in Japan (Matuo \& Motohashi, 1967), United States (Hubbard \& Gerik, 1993), Taiwan (Huang \& Lo, 1998), Iran (Millani et al., 1999), Italy (Garibaldi et al., 2002), and Portugal (Pasquali et al., 2007). Three FOLac races have been identified (Fujinaga et al., 2003) and Japan is the only country where all three races are present (Fujinaga et al., 2001; 2003; Yamauchi et al., 2004). Race 1 is the most widespread around the world with reports in Italy, Portugal, Taiwan, Iran, and the United States (Pasquali et al., 2005) and race 3 has been reported in Taiwan (Chang et al., 2011).

The most commonly used strategy for FOLac race determination is based upon the ability of the isolates to induce (or not) wilt symptoms in a set of differential lettuce cultivars (Ogiso et al., 2002; Fujinaga et al., 2003), which is a cumbersome and time-consuming approach. The development of PCR-based molecular markers for FOLac race determination (Pasquali et al., 2007; Mbofung \& Pryor, 2010) is useful for increasing the diagnostic power and conducting large scale survey of races. However, the usefulness of FOLac race-specific PCR primers is yet to be demonstrated for distinct groups of fungal isolates from Neotropical areas of the world.

In Brazil, lettuce vascular wilt caused by $F$. oxysporum isolates was first reported in Espírito Santo State (Ventura \& Costa, 2008), and later in other lettuce production areas of the country. However, a thorough understanding of the causal agent of the disease in Brazil is lacking, especially the potential presence of distinct FOLac races associated with this disease.

In this context, the objectives of this study were to 1) assess the virulence profile and host specificity of $F$. oxysporum isolates associated with lettuce vascular wilt, 2) identify FOLac races based on a set of differential lettuce cultivars and 3) assess a PCR protocol for detection and identification of FOLac race 1 isolates. 


\section{MATERIAL AND METHODS}

\section{Collection of isolates}

Thirty-one Fusarium isolates associated with lettuce plants displaying wilt symptoms and intense brownish color of the vascular vessels were collected in seven Brazilian States (Rio Grande do Sul, Santa Catarina, Paraná, São Paulo, Rio de Janeiro, Minas Gerais, and Espírito Santo) and in the Federal District between the years of 2008 to 2012 (Table 1). The isolates were obtained from symptomatic stem segments under aseptic conditions. Affected tissues were washed with tap water for two minutes, disinfested with $70 \%$ alcohol for one minute, washed again with sterile distilled water for 30 seconds, and air-dried on the laboratory bench. Five stem segments were allocated into equidistant points within Petri dishes containing Potato Dextrose Agar medium supplemented with $20 \mathrm{mg}$ of tetracycline (PDA-t). The Petri dishes were maintained in a growth chamber for
$12 \mathrm{~h}$ dark/light cycle at $25^{\circ} \mathrm{C}$ for three days. Thereafter, the fungus was transferred to a distinct Petri dish containing PDA-t medium aiming to obtain pure cultures. The isolates were assigned to species based on morphological description in the literature (Nelson et al., 1983; Leslie and Summerell, 2006). The isolates were maintained in Petri dishes containing PDA and in glass vials filled with sterile-distilled water (Castellani, 1963) and deposited in the culture collection of plant pathogenic fungi "Professora Maria Menezes" - CMM (Table 1).

\section{Inoculation procedures}

Three mycelial discs (5 $\mathrm{mm}$ in diameter each) were obtained from five-day old cultures grown in PDA-t and placed in Erlenmeyer flasks containing $100 \mathrm{~mL}$ of Potato + Dextrose liquid medium. These flasks were shaken for ten days $\left(25^{\circ} \mathrm{C}\right.$ and $12 \mathrm{~h}$ dark/light cycle) to induce microconidia production. After this treatment, the suspension was passed

TABLE 1 - Information and attributes of 31 Fusarium oxysporum isolates associated with lettuce (Lactuca sativa L.) wilt in locations across seven States and in the Federal District, Brazil.

\begin{tabular}{|c|c|c|c|c|c|}
\hline $\begin{array}{l}\text { Isolate } \\
\text { code }\end{array}$ & $\begin{array}{c}\text { Location } \\
\text { (municipality - state) }\end{array}$ & Year & Formae speciales $^{1}$ & Pathogenicity $^{2}$ & CMM code ${ }^{3}$ \\
\hline Fus-171 & Alegre - ES & 2008 & lactucae & + & CMM-3569 \\
\hline Fus-172 & Alegre - ES & 2008 & lactucae & + & CMM-3570 \\
\hline Fus-173 & Antônio Carlos - SC & 2008 & lactucae & + & CMM-3573 \\
\hline Fus-174 & Antônio Carlos - SC & 2008 & lactucae & + & CMM-3584 \\
\hline Fus-187 & Caratinga - MG & 2009 & lactucae & + & CMM-3589 \\
\hline Fus-202 & Muriaé - MG & 2009 & lactucae & + & CMM-3574 \\
\hline Fus-203 & Marechal Floriano - ES & 2009 & lactucae & + & CMM-3592 \\
\hline Fus-205 & Santa Cruz do Rio Pardo - SP & 2009 & lactucae & + & CMM-3575 \\
\hline Fus-206 & Paulínia - SP & 2009 & lactucae & + & CMM-3593 \\
\hline Fus-207 & Campinas - SP & 2010 & lactucae & + & CMM-3576 \\
\hline Fus-208 & Nova Friburgo - RJ & 2009 & lactucae & + & CMM-3694 \\
\hline Fus-209 & Nova Friburgo - RJ & 2009 & lactucae & + & CMM-3577 \\
\hline Fus-210 & Sumidouro - RJ & 2009 & lactucae & + & CMM-3595 \\
\hline Fus-219 & Colombo - PR & 2010 & lactucae & + & CMM-3580 \\
\hline Fus-220 & Colombo - PR & 2010 & lactucae & + & CMM-3581 \\
\hline Fus-221 & Colombo - PR & 2010 & Non-pathogenic & - & \\
\hline Fus-222 & Itajaí - SC & 2010 & lactucae & + & CMM-3583 \\
\hline Fus-223 & São José dos Pinhais - PR & 2010 & lactucae & + & CMM-3596 \\
\hline Fus-224 & São José dos Pinhais - PR & 2010 & Non-pathogenic & - & - \\
\hline Fus-225 & São José dos Pinhais - PR & 2010 & Non-pathogenic & - & - \\
\hline Fus-227 & Itajaí - SC & 2010 & lactucae & + & CMM-3597 \\
\hline Fus-237 & Brasília - DF & 2011 & Non-pathogenic & - & \\
\hline Fus-240 & Pelotas - RS & 2011 & lactucae & + & CMM-3600 \\
\hline Fus-241 & Santa Cruz do Rio Pardo - SP & 2011 & lactucae & + & CMM-3601 \\
\hline Fus-242 & Santa Cruz do Rio Pardo - SP & 2011 & lactucae & + & CMM-3602 \\
\hline Fus-243 & Santa Cruz do Rio Pardo - SP & 2011 & lactucae & + & CMM-3603 \\
\hline Fus-244 & Marechal Floriano - ES & 2011 & lactucae & + & CMM-3605 \\
\hline Fus-252 & Santa Cruz do Rio Pardo - SP & 2011 & lactucae & + & CMM-3606 \\
\hline Fus-253 & Marechal Floriano - ES & 2011 & lactucae & + & CMM-3655 \\
\hline Fus-254 & Três Pontas - MG & 2012 & lactucae & + & CMM-3656 \\
\hline Fus-255 & Três Pontas - MG & 2012 & lactucae & + & CMM-3657 \\
\hline
\end{tabular}

isolates were assigned to a formae speciales based on pathogenicity and molecular assays.

${ }^{2}$ Pathogenicity assays were conducted using three lettuce cultivars. $(+)=$ isolate able to induce disease; $(-)=$ no-pathogenic isolate

${ }^{3}$ Code of the pathogenic isolates deposited in the culture collection of plant pathogenic fungi "Professora Maria Menezes" - CMM. 
through a double-layer gauze filter in order to remove mycelium fragments. Spore concentration was determined using an hemocytometer and adjusted to a concentration of $2 \times 10^{6}$ microconidia/mL. All 31 isolates associated with lettuce wilt were employed in the pathogenicity tests using three commonly grown lettuce cultivars ('Elisa', 'Vera' and 'Red Salad Bowl'). The seedlings were produced in polystyrene trays $(68 \mathrm{~cm} \times 34 \mathrm{~cm})$ with 128 cells filled with commercial solid substrate (Bioplant ${ }^{\mathbb{}}$; Nova Ponte, MG). The trays were kept in a greenhouse free of pest and pathogen infestation with daily irrigation until transplanting and without pesticide applications. Inoculation was performed in 25-day old seedlings by dipping the apical region of their roots (cut approximately $2 \mathrm{~cm}$ from the top by sterile scissors) in $50 \mathrm{~mL}$ of a conidial suspension for three minutes. Immediately after inoculation, the seedlings were transplanted individually to $1 \mathrm{~L}$ plastic pots containing sterilized soil. After that, $3 \mathrm{~mL}$ of the conidial suspension were added to the collar area of each seedling. The pots were irrigated two hours prior to inoculation until soil saturation (Santos, 1999).

\section{Host range experiment}

The isolates were inoculated in a group of six species from the Asteraceae family including lettuce (cv. Elisa), Cichorium endivia L., Cichorium intybus L., Sonchus oleraceus L., Emilia sonchifolia L., Bidens pilosa L. and Tagetes erecta L. as well as several species from other botanic families such as Solanaceae (Solanum lycopersicum L., Capsicum annuum L., Nicotiana tabacum L.), Malvaceae (Gossypium hirsutum L.), Fabaceae (Phaseolus vulgaris L.), and Lamiaceae (Ocimum basilicum L.). Inoculation was made using the root dipping method of the wounded root system essentially as described. Mock-inoculated plants of each species were kept in the same greenhouse conditions to serve as controls. Evaluation was done at 20 to 25 days after inoculation, initially by visual analysis of leaf chlorosis, overall wilt, and vascular browning.

\section{Race determination based on a differential set of lettuce cultivars}

The isolates were inoculated in a set of cultivars comprising: 'Patriot' (susceptible to all races), 'Costa Rica No. 4' (resistance specific to race 1) and 'Banchu Red Fire' (resistance specific to race 2 ). The seedlings were produced in polystyrene trays $(68 \mathrm{~cm} \times 34 \mathrm{~cm})$ with 128 cells filled with commercial solid substrate (Bioplant ${ }^{\circledR}$; Nova Ponte, MG). The seedlings were removed from the substrate at 25 days after sowing. Inoculation production and inoculation procedures were essentially as described previously. Conidial suspension was adjusted to $2 \times 10^{6}$ microconidia. $\mathrm{mL}^{-1}$. The evaluation was done 20 days after inoculation and the plant reaction was assessed using a disease severity ordinal and descriptive scale ranging from 1 to 5 (Santos, 1999). The isolates were classified as pathogenic/virulent to a given cultivar when the average disease severity grade was above score 2 of the scale (plants without vascular wilt and chlorosis symptoms but with vascular browning; score 1: plant without symptoms). Isolates unable to induce disease in all three cultivars were classified as non-pathogenic or avirulent. Race 1 isolates are pathogenic/virulent only to the cultivars 'Patriot' and 'Banchu Red Fire', whereas race 2 isolates are pathogenic only to 'Patriot' and 'Costa Rica No. 4'. Isolates able to induce disease in all three accessions would represent race 3, which has been reported only in Japan and Taiwan (Chang et al. 2011).

\section{Molecular FOLac race identification}

Twenty-seven isolates characterized as being FOLac race 1 based on the inoculation assays in the set of differentials were tested in additional molecular race phenotyping assays. One isolate of $F$. oxysporum f. sp. lycopersici (FOL) race 3 (named Fus-191) and one nonpathogenic F. oxysporum isolate (Fus-237) were also included. Fungal genomic DNA was extracted using the CTAB protocol with minor modifications (Boiteux et al., 1999). PCR reaction was carried out using the primer par Hani3' (5'CCC-TCC-AAC-ATT-CAA-CAA-CTG3') and Hanilatt3rev (5'ATT-CAC-TGT-ACA-CCA-ACC-TTTT3'), which were designed for specific discrimination of FOLac race 1 isolates (Paquali et al, 2007). PCR reaction was composed of $3 \mu \mathrm{L}$ of fungal genomic DNA $(20 \mathrm{ng} / \mathrm{mL})$, $2 \mu \mathrm{L} \mathrm{10X}$ buffer (100 mM Tris-HCl, $500 \mathrm{mM} \mathrm{KCl}, \mathrm{pH} 8.3$ ), $0.48 \mu \mathrm{L} \mathrm{MgCl}_{2}(50 \mathrm{mM}), 2 \mu \mathrm{L}$ dNTPs $(2.5 \mathrm{M}$ each $), 0.2 \mu \mathrm{L}$ Taq DNA polymerase ( 5 units $\mu \mathrm{L}$ ), $3 \mu \mathrm{L}$ of each primer and $6.32 \mu \mathrm{L}$ Milli-Q water, with a final reaction volume of $20 \mu \mathrm{L}$. Samples were amplified in one My $\mathrm{Cycler}^{\mathrm{TM}}$ (BIO RAD) thermocycler. The amplification program employed was carried out as follows: initial cycle $\left(94^{\circ} \mathrm{C} / 1 \mathrm{~min}\right)$, ten denaturation cycles $\left(94^{\circ} \mathrm{C}\right.$ for 15 seconds), annealing at $66^{\circ} \mathrm{C}(30 \mathrm{~s})$. The annealing temperature was reduced by $0.5^{\circ} \mathrm{C}$ after each cycle, and then the program was shifted to 30 denaturation cycles $\left(94^{\circ} \mathrm{C}\right.$ for 15 seconds), $61^{\circ} \mathrm{C}$ annealing temperature (30 seconds) and extension of $72^{\circ} \mathrm{C}$ (30 seconds). A final extension cycle was carried out at $72^{\circ} \mathrm{C}$ for 2 minutes. The introduction of these final 30 cycles was a modification in relation to the original protocol described by Pasquali et al. (2007). Amplicons were analyzed in agarose gel $(1 \% \mathrm{p} / \mathrm{v})$ eletrophoresis, stained with ethidium bromide and visualized under UV light.

\section{RESULTS AND DISCUSSION}

The thirty-one purified Fusarium isolates showed the typical morphological features of the species $F$. oxysporum (Leslie \& Summerell, 2006). Twenty-seven isolates were able to infect 'Elisa' and 'Vera' cultivars and were re-isolated from the diseased plants, thus fulfilling Koch's postulates. Four isolates were non-pathogenic to this subset of lettuce cultivars, including the one from the Federal District (Fus237). The 'Red Salad Bowl' cultivar exhibited a resistant reaction against all isolates. Taken together, these results 
allowed us to assign all pathogenic isolates to $F$. oxysporum f. sp. lactucae. The inoculation-based assay is so far the only available method for distinguishing saprophytic (non-pathogenic) isolates from pathogenic $F$. oxysporum isolates, since they are quite similar in terms of cultural and morphological traits (Booth, 1971; Burgess et al., 1994).

Additionally, the 27 pathogenic isolates were not able to induce wilt symptoms in the set of Asteraceae species as well in host species of other botanical families tested in our study, thus suggesting the specificity of these isolates to lettuce. Previously, Ventura \& Costa (2008) described the causal agent of lettuce wilt disease in Brazil only to the species level (F. oxysporum).

The reaction of the race differentials to the set of pathogenic isolates was quite similar. 'Patriot' and 'Banchu Red Fire' were highly susceptible to all isolates (but not to the four nonpathogenic isolates), whereas 'Costa Rica No. 4' was found to be resistant, indicating so far the exclusive presence of FOLac race 1 in Brazil, which has been also found in the United States, Japan, Italy, Portugal, Taiwan and Iran (Fujinaga et al., 2001; McCreight et al., 2003; 2005; Garibaldi et al., 2004b; Pasquali et al., 2007).

Amplicons corresponding to the region between the clusters of class II transposons (Hua-Van et al., 2000) were amplified via PCR assays for the 27 pathogenic isolates. These amplicons were not present in the control FOL race 3 (isolate Fus. 191) and in one non-pathogenic $F$. oxysporum (Fus. 237) isolate (Figure 1). The size of the amplicon was approximately $200 \mathrm{bp}$. This same primer pair was employed by Pasquali et al. (2007) for specific detection of FOLac race 1 using a collection of race 1 isolates from Italy, United States (States of Arizona and California), Portugal, Taiwan, and Japan. In fact, these primers have been previously used as powerful diagnostic tools for FOLac race 1 isolates, but they were not evaluated with isolates from Neotropical areas of the world. All the results combined suggest that all 27 pathogenic isolates belong to FOLac race 1 .

Molecular techniques are important tools to discriminate fungal species with intimate genetic relationships where few morphological diagnostic traits are available (Wuff et al., 2010) as well as to differentiate isolates within the same species (Chandra-Nayaka et al., 2010). In Fusarium, the identification to species based exclusively upon morphological information is challenging. This genus is especially difficult to fungal taxonomists because either the lack of informative traits or the phenotypic instability of several traits, which expression might be affected by in vitro and in vivo conditions (Fravel et al., 2003). Our study showed that the PCR primer pair Hani and Hanilatt3rev (Hua-Van et al., 2000) might reliably be used to discriminate FOLac race 1 isolates from Brazil. Robust PCR assays as this one able to differentiate isolates at their formae speciales and race levels are useful for large-scale surveys of fungal isolates.

It is well known from the literature that distinct formae speciales of $F$. oxysporum are very efficiently seed-transmitted. In fact, the spread of FOLac race 1 isolates into several countries of distinct continents in a short period of time suggests its spread via infested seed, although this has not been conclusively documented (Garibaldi et al., 2004a; Mbofung \& Pryor, 2010). Likewise, the presence of FOLac race 1 in several and distant lettuce production regions of Brazil suggests that this pathogen may have been introduced into the country via infected seeds. Further molecular phylogenetic analysis of the Brazilian isolates might allow assessing whether these isolates are either endemic or introduced into the country from abroad.

The control of Fusarium wilt of lettuce via fungicide and soil desinfestation treatments is usually not economically and ecologically feasible. An effective

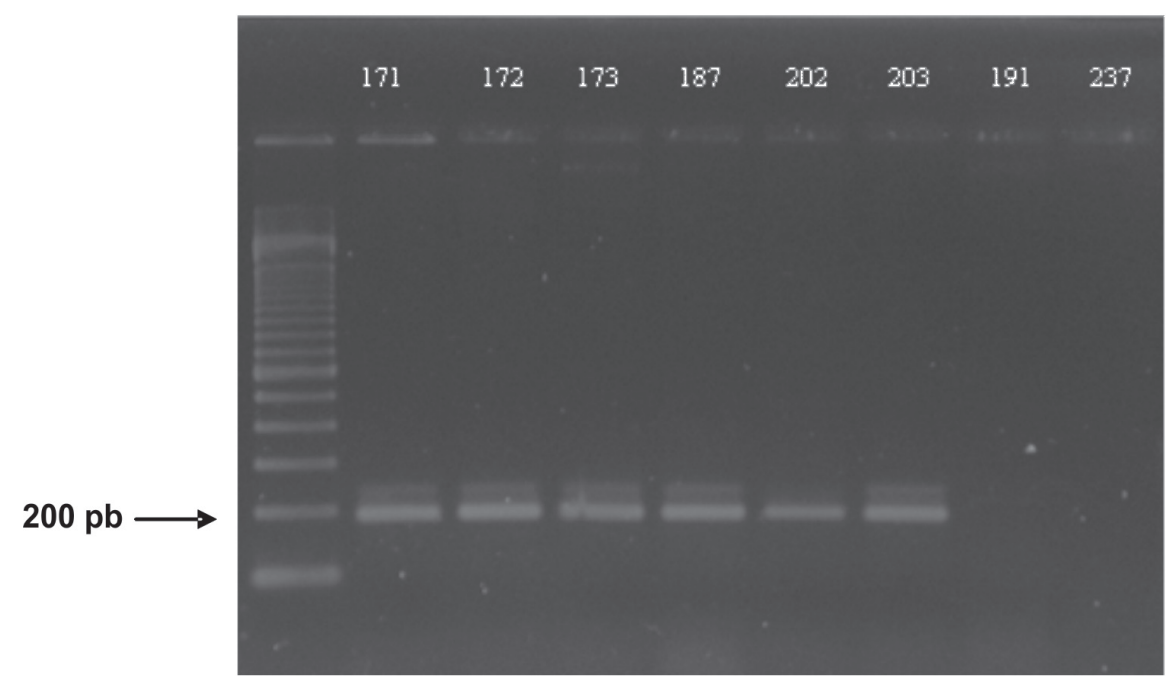

FIGURE 1 - PCR amplicons of around 200 bp obtained with the Fusarium oxysporum f. sp. lactucae (FOLac) race 1-specific prime pair Hani (5' GAA-CCC-TCC-AACATT-CAA-CA 3') and Hanilatt3rev (5', CCT-CCA-ACA-TTC-AAC-AAC-AAT-G 3'). The lanes 171, 172, 173, 187, 202, and 203 are PCR the amplicons obtained with genomic DNA extracted from six distinct isolates that were pathogenic to lettuce. The lane 191 corresponds to the results obtained with the same prime pair using genomic DNA extracted from one isolate of F. oxysporum f. sp. lycopersici (FOL) race 3 and the lane 237 corresponds to the results obtained with one F. oxysporum isolate nonpathogenic to lettuce. $\mathrm{M}=$ Size marker $1 \mathrm{~Kb}$ Plus DNA Ladder ${ }^{\circledR}$ (Invitrogen). 
disease management has been achieved using pathogenfree propagative (seed) material, crop rotation and resistant cultivars (McCreight et al., 2003; 2005). Information about the genetic variability of the pathogen is important when breeding for disease resistance and the identification of a single race of the FOLac present in Brazil provides useful information for lettuce breeding programs in the country. This will help to develop resistant cultivars using either 'Red Salad Bowl' or 'Costa Rica No. 4', as well as other already selected commercial cultivars (Cabral \& Reis, 2013), as sources of resistance alleles. The information is also important to growers and extension service, guiding them to select resistant cultivars in at least seven Brazilian States. The ability of the fungus to transmit through infected seeds and the high yield losses imposed by Fusarium wilt also indicates the need for preemptive breeding programs aiming to pyramid distinct race-specific genetic factors into a single cultivar even for races not yet present in Brazil.

\section{REFERENCES}

Booth C (1971) The genus Fusarium. Kew, England, Commonwealth Mycological Institute.

Boiteux LS, Fonseca MEN, Simon PW (1999) Effects of plant tissue and DNA purification method on randomly amplified polymorphic DNA based genetic fingerprinting analyses is carrot. Journal of the American Society for Horticultural Science 124:3238.

Burgess LW, Summerell BA, Bullock S, Gott KP, Backhouse D (1994) Laboratory manual for Fusarium research, 3rd ed., Sidney, Australia, University of Sidney.

Cabral CS, Reis A (2013) Screening of lettuce accessions for resistance to Fusarium oxysporum f. sp. lactucae race 1. Tropical Plant Pathology 38:272-281.

Castellani A (1963). The "water cultivation" of pathogenic fungi. Journal of Tropical Medicine and Hygiene 66:283-286.

Chang P, Lin Y, Lai P, Chang T, Wan Y, Huang J (2011) Pathological and molecular race determinations of Fusarium oxysporum f. sp. lactucae from Taiwan. Phytopathology 101(6, supplement):31.

Chandra-Nayaka S, Udaya Shannkar AC, Niranjana SR, Reddy MS, Prakash HS (2010) Detection and quantification of fumonisins from Fusarium verticillioides in maize grown in southern India. World Journal Microbiology Biotechnology 26:71-78.

Fravel D, Olivain C, Alabouvette C (2003) Fusarium oxysporum and its biocontrol. New Phytology 157:493-502.

Fujinaga M, Ogiso H, Tsuchiya N, Saito H (2001) Physiological specialization of Fusarium oxysporum f. sp. lactucae, a causal organism of fusarium root of crisp head lettuce in Japan. Journal of General Plant Pathology 667:205-206.

Fujinaga M, Ogiso H, Tuchiya N, Saito H, Yamanaka S, Nozue M, Kojima M (2003) Race 3, a new race of Fusarium oxysporum $\mathrm{f}$. sp. lactucae determined by a differential system with commercial cultivars. Journal of General Plant Pathology 69:23-28.

Garibaldi A, Gilardi G, Gullino ML (2002) First report of Fusarium oxysporum on lettuce in Europe. Plant Disease 86:1052.

Garibaldi A, Gilardi G, Gullino ML (2004a) Seed transmission of Fusarium oxysporum f. sp. lactucae. Phytoparasitica 32:61-65.

Garibaldi A, Gilardi G, Gullino ML (2004b)Varietal resistance of lettuce to Fusarium oxysporum f. sp. lactucae. Crop Protection 23:845-851.

Huang JH, Lo CT (1998) Wilt of lettuce caused by Fusarium oxysporum in Taiwan. Plant Pathology Bulletin 7:150-153.

Hua-Van A, Davière JM, Kaper F, Langin, T, Daboussi MJ (2000) Genome organization in Fusarium oxysporum: Clusters of class II transposons. Current Genetics 37:339-347.

Hubbard JC, Gerik JS (1993) A new disease of lettuce incited by Fusarium oxysporum f. sp. lactucum forma specialis nov. Plant Disease 77:750-754.

Leslie JF, Summerell BA (2006) The Fusarium laboratory manual. Ames, Blackwell.

McCreight JD, Matheron ME, Tickes BR, Platts, B (2003). Occurrence of fusarium root rot race 1 on lettuce in Yuma, Arizona. Hort Science 38:664.

McCreight JD, Matheron ME, Tickes BR, Platts, B (2005) Fusarium wilt race 1 on lettuce. Hort Science 40:529-531.

Mbofung GY, Pryor BM (2010) A PCR-based assay for detection of Fusarium oxysporum f. sp. lactucae in lettuce seed. Plant Disease 94:860-866.

Matuo T, Motohashi S (1967) On Fusarium oxysporum f. sp. lactucae n. f. causing root rot of lettuce. Transactions of Mycological Society of Japan 8:13-15.

Millani MJ, Erebarian HR, Alizadeh A (1999) Occurrence of fusarium wilt of lettuce in Shahr-Ray, Varamim and Karaj areas. Iran Journal of Plant Pathology 35:44.

Nelson PE, Toussoun TA, Marasas WFO (1983) Fusarium species: an illustrated manual for identification. University Park, The Pennsylvania State University Press.

Ogiso H, Fujinaga M, Saito H, Takehara T, Yamanaka S (2002) Physiological races and vegetative compatibility groups of Fusarium oxysporum f. sp. lactucae isolated from crisphead lettuce in Japan. Journal of General Plant Pathology 68:292-299.

Pasquali M, Dematheis F, Gilardi G, Gullino ML, Garibaldi A (2005) Vegetative compatibility groups of Fusarium oxysporum $\mathrm{f}$. sp. lactucae from lettuce. Plant Disease 89:237-240.

Pasquali M, Dematheis F, Gullino ML, Garibaldi A (2007) Identification of race 1 of Fusarium oxysporum f. sp. lactucae on lettuce by inter-retrotranposon sequence-characterized amplified region technique. Phytopathology 97:987-996.

Santos JRM (1996) Methodology for screening tomato to Fusarium wilt, Verticillium wilt, gray leaf spot, early blight, and Septoria leaf spot. Pages 164-166. In: Proceedings of the international symposium on tropical tomato diseases, ASHS: IPA. Alexandria, USA.

Scott JC, Kirkpatrick SC, Gordon TR (2010) Variation in susceptibility of lettuce cultivars to fusarium wilt caused by Fusarium oxysporum f. sp. lactucae. Plant Pathology 59:139146.

Wulff EG, Sorensen JL, Lübeck M, Nielsen KF, Thrane U, Torp J (2010) Fusarium spp. associated with rice Bakanae: ecology, 


\section{C.S. Cabral et al.}

genetic diversity, pathogenicity and toxigenicity. Environmental Microbiology 12:649-657.

Yamauchi N, Shimazu J, Horiuchi S, Satou M, Shirakawa T (2004) Physiological races and vegetative compatibility groups of butterhead lettuce isolates of Fusarium oxysporum f. sp. lactucae in Japan. Journal of General Plant Pathology 70:308-313.

Ventura JA, Costa H (2008) Fusarium wilt caused by Fusarium oxysporum on lettuce in Espirito Santo, Brazil. Plant Disease 92:976.

TPP-2013-0160

Submitted: 23 September 2013

Revisions requested: 2 November 2013

Accepted: 16 January 2014

Section Editor: Adalberto C. Café Filho 